\title{
Supplemental permanent incisor teeth
}

\author{
Rajni Nagpal, ${ }^{1}$ Naveen Manuja, ${ }^{2}$ I K Pandit, ${ }^{3}$ Mandeep Rallan ${ }^{4}$
}

${ }^{1}$ Department of Conservative Dentistry, Kothiwal Dental College, Moradabad, Uttar Pradesh, India

${ }^{2}$ Department of Pedodontics, Kothiwal Dental College and Research Centre, Moradabad, Uttar Pradesh, India

${ }^{3}$ Department of Pedodontics and Preventive Dentistry, DAV Dental College, Yamuna Nagar, Haryana, India ${ }^{4}$ Department of Pediatric Dentistry, Teerthanker

Mahaveer Dental College \& Research Centre, Moradabad, Uttar Pradesh, India

\section{Correspondence to} Dr Mandeep Rallan, drmandeeprallan@gmail.com

Accepted 24 February 2014

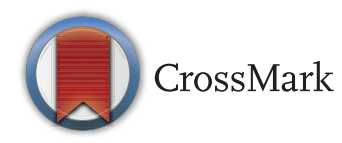

To cite: Nagpal $R_{\text {, }}$ Manuja N, Pandit IK, et al. BMJ Case Rep Published online: [please include Day Month Year] doi:10.1136/ bcr-2013-201019

\section{DESCRIPTION}

A 9-year-old boy reported to the outpatient department for a routine dental check-up. Familial, medical and dental histories were unremarkable. General and extra-oral examination showed no abnormality. Dental examination revealed the presence of six permanent maxillary incisor teeth (figure 1). Panoramic and occlusal radiographs showed the presence of six maxillary incisor teeth belonging to the permanent dentition (figures 2 and 3). The patient was referred to a general physician to rule out any syndrome associated with these supplemental teeth.

On the basis of the dental findings and the absence of any associated disorder or syndrome, these teeth were differentiated as supplemental incisors.

Supernumerary teeth or hyperdontia are those that are additional to the normal complement of teeth. Supernumerary teeth can be classified according to their location in the dental arch: mesiodens, paramolar and distomolar or according

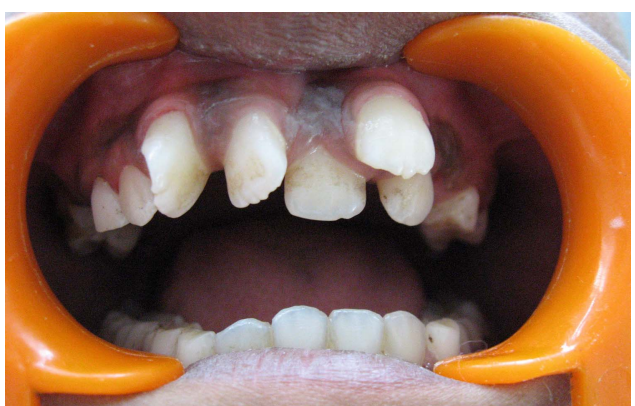

Figure 1 Clinical photograph showing six maxillary permanent incisors.

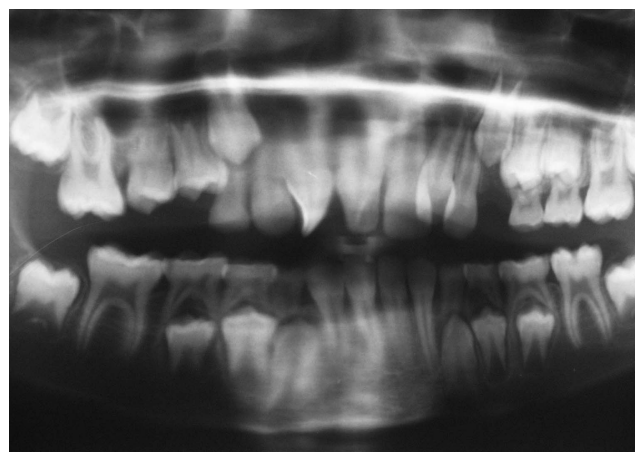

Figure 2 Panoramic radiograph showing supplemental incisors.

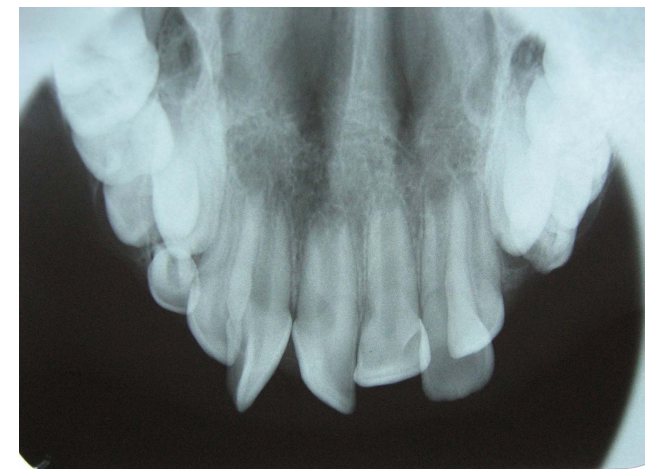

Figure 3 Occlusal radiograph showing supplemental incisors.

to their morphological forms: conical, tuberculate, supplemental and odontome. ${ }^{1}{ }^{2}$ Clinically, supernumerary teeth are able to cause different local disorders, including, retention of the primary tooth, delayed eruption of the permanent tooth, ectopic eruption, tooth displacement, follicular cysts and other alterations requiring surgical or orthodontic intervention. ${ }^{3}$

\section{Learning points}

- Supernumerary teeth are considered one of the most significant dental anomalies during the primary and early mixed dentition stages.

- Supernumerary teeth may cause diastema, root resorption, malformations such as dilacerations and loss of vitality of adjacent teeth.

- To avoid the complications of supernumerary teeth, extraction of these teeth is a general rule.

Competing interests None.

Patient consent Obtained.

Provenance and peer review Not commissioned; externally peer reviewed.

\section{REFERENCES}

1 Manuja N, Nagpal R, Singh M, et al. Delayed eruption of maxillary permanent central incisors due to bilateral tuberculate supernumerary teeth: case report. J Dent Child 2010;77:106-10.

2 Mitchell L. Supernumerary teeth. Dent Update 1989;16:65-9.

3 Ziberman Y, Malron M, Shteyer R. Assessment of 100 children in Jerusalem with supernumerary teeth in the premaxillary region. J Dent Child 1992:59:44-7. 
Copyright 2014 BMJ Publishing Group. All rights reserved. For permission to reuse any of this content visit http://group.bmj.com/group/rights-licensing/permissions.

BMJ Case Report Fellows may re-use this article for personal use and teaching without any further permission.

Become a Fellow of BMJ Case Reports today and you can:

- Submit as many cases as you like

- Enjoy fast sympathetic peer review and rapid publication of accepted articles

- Access all the published articles

- Re-use any of the published material for personal use and teaching without further permission

For information on Institutional Fellowships contact consortiasales@bmjgroup.com

Visit casereports.bmj.com for more articles like this and to become a Fellow 